УДК 334.758.2

\title{
ПРОБЛЕМЫ ПОГЛОЩЕНИЯ И СЛИЯНИЯ В СФЕРЕ МАЛОГО И СРЕДНЕГО БИЗНЕСА В РОССИЙСКОЙ ФЕДЕРАЦИИ
}

\author{
Коновалова Ирина Александровна \\ к.э.н., доцент
}

Парфененкова Арина Николаевна

ФГБОУ ВО «Северо-Кавказский Федеральный Университет»

\begin{abstract}
Аннотация: в настоящий момент сфера малого и среднего бизнеса в России служит источником инноваций и ядром в продвижении высокотехнологических услуг и сопутствующих компонентов. Для того, чтобы малый бизнес функционировал бесперебойно, практикуются сделки слияний и поглощений, но сделки имеют ряд вытекающих последствий: неправильный прогноз слияний и поглощений, экспроприация предпринимательских идей, ухудшение текущей производственной деятельности так как процессы связаны с реорганизаций компаний.
\end{abstract}

Ключевые слова: слияния, поглощения, малый и средний бизнес, оценка бизнеса, оценка активов, инновационная деятельность, управленческая деятельность, соглашения, реструктуризация.

\section{PROBLEMS OF ACQUISITIONS AND MERGERS IN THE SPHERE OF SMALL AND MEDIUM-SIZED BUSINESSES IN THE RUSSIAN FEDERATION}

\section{Konovalova Irina Aleksandrovna Parfenenkov Arina Nikolaevna}

\begin{abstract}
: at the moment, the sphere of small and medium-sized businesses in Russia serves as a source of innovation and a core in the promotion of high-tech services and related components. In order for small businesses to function smoothly, mergers and acquisitions are practiced, but the transactions have a number of consequences: incorrect forecast of mergers and acquisitions, expropriation of entrepreneurial ideas, deterioration of current production activities as the processes are associated with the reorganization of companies.
\end{abstract}


Key words: mergers, acquisitions, small and medium-sized businesses, business valuation, asset valuation, innovation, management, agreements, restructuring.

Mergers are voluntary mergers of assets of two or more companies, whereby votes are distributed in the board of directors in accordance with the assets invested in the object of the merger. Most often, mergers occur for the purposes of mutual complementarity of patent technologies, product diversification, including for the consolidation and deeper scaling of the company in the domestic (or foreign) market.

Recent developments in the global economy, the imposition of sanctions, as well as expectations of greater clarity regarding the government's plans for the digital transformation of the economy and the implementation of the program of national projects have created a general uncertainty in the Russian market, which directly affected the number of major investment transactions. Nevertheless, despite this, Russia has managed to make significant progress in the diversification of the economy and to start successfully developing new areas of activity.

Takeover transactions are transactions caused by the need to attach the assets of one company to the assets of another company. Such situations occur when a firm is on the verge of bankruptcy, or when a larger company is interested in acting as the owner of the technology or service that was produced by the takeover object.

This type of transaction is carried out in order for the company to get rid of unprofitable assets, as a result of which assets are exchanged, production is diversified, and also encourages the company to enter the foreign market with increased growth rates. These transactions contribute to increased consolidation of the production base, resulting in lower costs and increased intensive use of assets. Among the negative consequences, we can distinguish a decrease in the introduction of innovations, as a result of which business processes slow down [2, p. 2].

The reasons for mergers and acquisitions in the Russian Federation for 2020 are the following:

- the desire of business owners to stabilize the inflow of both monetary resources and human resources. Human resources took a large share in surveys for managers who were owners of takeover objects: most managers are interested in improving the skills of their employees, and resources to promote this idea can be taken from growing assets as a result of the takeover;

- interest in getting rid of uneconomic resources, which hampered the efficiency of the business as small and medium business in the Russian Federation 
has the characteristic of lower reputation, in contrast to large (more than 50 percent of buyers estimate the future growth rates and prefer the more reliable firms with a higher credibility);

- stability of small business owners in the issue of stable cash flow of assets. Entrepreneurs try not to take risks and not to invest in venture projects, as investment activities are fraught with bankruptcy for the owners. Large enterprises, on the contrary, try to carry out merger transactions with small businesses, as they are a source of technological breakthrough, and, accordingly, a promising partner in the occupation of a certain area of the economy;

- increasing the value of companies by joining the assets of another organization, regardless of the availability of innovative ideas, the main thing for this reason is the creation of a stable subsidiary or division;

- strengthening the position of your own company in the domestic and foreign markets. The reason can be seen in "Royal Caribbean Group", which finally signed a contract to sell the company (brand) "Azamara" (worth 201 million dollars.) a private investment company that focuses on consumer, distributor and retail investment transactions.

- diversification of risks, the type of activity, which can also be traced in the above example [1, p. 12].

Since mergers and acquisitions are associated with the reorganization of the merger objects, a number of objective negative consequences can be identified, which leads to the conclusion that mergers and acquisitions of small businesses on the territory of the Russian Federation are unwise:

- incorrect forecast of mergers and acquisitions. On the example of mergers and acquisitions of companies in the Moscow region: many single establishments will disappear, since they are primarily objects of large network companies. The small restaurant business in Russia is suffering not only because of the wrong implementation strategy and investment of assets, but also because of the problems associated with the pandemic. Small enterprises are absorbed by large ones, as a result of which the restaurant business "sags" and goes bankrupt due to the lack of improper management of large companies: new problems arise due to nonattendance, burnout of assets and low demand;

- expropriation of entrepreneurial ideas. Many companies, both in Russian practice and on the world stage, have faced the fact that after the implementation of mergers and acquisitions, the ideas of small businesses are gradually silenced under the pressure of the parent companies, for which, after the acquisition or merger, the 
risks from the projects increase. As a result, this may affect the internal structure of the company and increase marginal costs;

- the deterioration of the current production activity is due to the fact that small and medium-sized enterprises, before the transactions were made, had their own unique business structure, which needs to be re-formed to meet the needs of a larger company. Strategies and aims are not the same due to the low level of analysis strategies and methods of conducting company's activities (no dock sales plans, records of assets and their use) [3, p. 223].

In view of the above problems, it is proposed to eliminate them by introducing the following strategies and norms for the development of small and medium-sized businesses in the structure of the Russian economy:

1. An increase in the number of lobbyists who will defend the rights of small and medium-sized businesses to function separately, without introducing large enterprises into the business structure, since many network companies do not take into account the uniqueness of the development of subjects in view of the desire to increase their own assets, this leads to the loss of the individual structure of the development of innovative industries;

2. Strengthening of legal norms that will promote the development of small businesses without unnecessary implementation in the internal policy of companies;

3. Increase in the number of personnel specialists who will be able to use both a scientific approach to building business models, and to compile the acquired knowledge about the promotion of small and medium-sized businesses.

The purpose of mergers and acquisitions is to concentrate all the forces of entrepreneurs in the direction of those areas that are not only a priority for the Russian economy, but also for financial stability. Therefore, to expand the full volume of its capacity, it is necessary to apply a number of economic tricks that lead to significant problems on the part of the development of the innovative potential of small businesses.

The above strategies will help Russian small and medium-sized businesses reduce the decline in the efficiency of the industry (since it is 4 times lower than in developed countries) and stimulate innovative breakthroughs, as well as their share in the economy.

\section{References}

1. Alexandrovskaya Yu. P. Assessment of the economic efficiency of investments in small businesses // Economics and Business: theory and practice. 2019. - No. 12-1. - p. 14. - An electronic copy is available on the website of nauch. 
electron. b-ki CyberLeninka. URL: https://cyberleninka.ru/article/n/otsenkaekonomicheskoy-effektivnosti-investitsiy-v-malyy-biznes (accessed 20.01.2021)

2. Baldina, Yu. A. The role and place of small and medium-sized businesses in modern economic conditions / Bulletin of the Udmurt University. Economics and Law series. 2018. Vol. 26. No. 4. [Electronic source] / URL: http://elibrary.ru /item.asp?id=26643676 (accessed 20.01.2021)

3. Demtsura, S. S. Maloe predprinimatelstvo: rol ' i problemy razvitiya [Small business: the role and problems of development]. 2019. No. 9. S. 456

(С) И.А. Коновалова, А.Н. Парфененкова, 2021 